PSICOLOGIA, SAÚDE \& DOENÇAS, 2017, 18(3), 699-711

ISSN - 2182-8407

Sociedade Portuguesa de Psicologia da Saúde - SPPS-www.sp-ps.pt

DOI: http://dx.doi.org/10.15309/17psd180306

\title{
BINGE EATING IN OBESITY: MAINLAND PORTUGAL AND SÃO MIGUEL, AZORES
}

\author{
Rita Albergaria (malbergaria@ispa.pt) ${ }^{1}$, Filipa Pimenta (filipa_pimenta@ispa.pt $)^{1,2}$, João Maroco \\ (jpmaroco@ispa.pt) ${ }^{1,2}$, Isabel Leal (ileal@ispa.pt) ${ }^{1,2}$, Teresa Albergaria (mtgas0012@gmail.com) ${ }^{3}$, \& Maria José \\ Bicudo $^{4}$ \\ ${ }^{1}$ ISPA-Instituto Universitário, Lisboa, Portugal; ${ }^{2}$ William James Center for Research, Portugal; ${ }^{3}$ Unidade Saúde Ilha de São \\ Miguel, Portugal; ${ }^{4}$ Universidade dos Açores, Portugal
}

\begin{abstract}
This study aimed to investigate if binge eating-BE in individuals with obesity is influenced by their eating behaviour, social support satisfaction, healthcare, lifestyle and sociodemographical variables. It also aimed to compare BE and body mass index-BMI between individuals from mainland Portugal $(n=117)$ and São Miguel, Azores $(n=70)$ - cluster of islands with the largest national obesity incidence. Participants completed the Binge Eating Scale, the Dutch Eating Behaviour Questionnaire and the Social Support Satisfaction Scale. It was used as a modelling of structural equations to construct the structural model, having BE as dependent variable. Emotional eating $(\beta=.26 ; p<.001)$, external eating $(\beta=.2 ; p<.001)$ and satisfaction with support from friends $(\beta=-.14 ; p=.004)$ predict the severity of BE. Also the level of educational level was associated to $\mathrm{BE}(\beta=-.11 ; p<.001)$. There was no association between $\mathrm{BE}$ and $\mathrm{BMI}$ $(\beta=.003 ; p=.68)$ or between individuals from mainland Portugal and São Miguel $(t(115,897)=-$ $1.38 ; p=.17)$, contrary to the BMI $(t(184,538)=3.57 ; p=.001)$. Interventions that promote adaptive strategies for management of emotional and external eating are suggested and also the development of friends network support in combination with health activities to attenuate the severity of BE. The absence of differences between the samples from mainland Portugal and the islands in relation to $\mathrm{BE}$ raises the hypothesis of other variables being able to explain the differences between the prevalence of obese individuals, other than the ones studied.
\end{abstract}

Keywords: binge eating; eating behaviour, social support satisfaction

\section{INGESTÃO COMPULSIVA NA OBESIDADE: PORTUGAL CONTINENTAL E SÃO MIGUEL, AÇORES}

RESUMO: Este estudo objetivou explorar se a ingestão compulsiva-IC em pessoas com obesidade é influenciada pelo comportamento alimentar, satisfação com o suporte social, variáveis sociodemográficas, de saúde e estilo de vida. E comparou a prática de IC e Índice Massa Corporal-IMC entre indivíduos de Portugal continental $(n=117)$ e de São Miguel, Açores $(n=70)$ - arquipélago com maior incidência nacional de obesidade. Os participantes preencheram a Escala de Ingestão Compulsiva, o Questionário Holandês do Comportamento Alimentar e a

\footnotetext{
Rua Jardim do Tabaco, n³4 1149-041, Lisboa, Portugal. Telf.:914282811. e-mail: malbergaria@ispa.pt
} 


\section{BINGE EATING IN OBESITY}

Escala de Satisfação com o Suporte Social. Utilizou-se a modelação de equações estruturais para construir o modelo estrutural, com variável dependente a IC. A ingestão emocional ( $\beta=.26 ; p<.001)$, a ingestão externa $(\beta=.2 ; p<.001)$ e a satisfação com os amigos $(\beta=-.14 ; p=.004)$ predizem a gravidade de IC. Também o nível de habilitações académicas se associou à IC ( $\beta=-$ $.11 ; p<.001)$. Não se verificou associação entre a IC e o IMC $(\beta=.003 ; p=.68)$. Nem diferenças entre os participantes insulares e os de Portugal continental relativamente à IC $(t(115,897)=-$ $1.38 ; p=.17)$, contrariamente ao IMC $(t(184,538)=3.57 ; p=.001)$. Sugerem-se intervenções promotoras de estratégias para a gestão da ingestão emocional e externa e o desenvolvimento de redes de apoio de amigos, conjugadas com atividades promotoras de saúde para a atenuação da gravidade da IC. A ausência de diferenças entre a amostra insular e continental relativamente à IC levanta a hipótese de outras variáveis explicarem as diferenças na prevalência de obesidade, que não as estudadas nesta investigação.

Palavras-chave: ingestão compulsiva, comportamento alimentar, satisfação com o suporte social

Recebido em 26 de Janeiro de 2017 / Aceite em 20 de Outubro de 2017

According to the World Health Organization (WHO, 2015) an individual with a body mass index (BMI) equal or above of $30 \mathrm{~kg} / \mathrm{m}^{2}$ experiences obesity. Obesity is a public health problem, considering the increase of its consequences on the world's panorama (WHO, 2000). By 2014 there were over 600 million adults with obesity (WHO, 2015); in mainland Portugal there were 16.2\% and in the Azores, national region with the highest incidence of obesity, there were $22.1 \%$ (Instituto Nacional de Estatística, 2015).

Obesity can generate or coexist with other clinical conditions (e.g., binge eating disorder - BED). The development and/or maintenance of the first condition may be associated, among others, with food intake; the later is influenced by psychosocial factors related to both selection and decision-making process of what is eaten (Leitão, Pimenta, de Herédia, \& Leal, 2013; Pfattheicher \& Sassenrath, 2014; Venzon \& Alchieri, 2014; Viana \& Sinde, 2003). The literature in the field has emphasised 3 types of eating behaviour: Emotional eating, i.e., excessive food intake in response of negative emotional status (Guenter, 2000; Natacci \& Júnior, 2011; Viana \& Sinde, 2003); External eating, that is, food intake in response to perceived external stimuli (e.g., the smell of food) (Magalhães \& Motta, 2012; Rebelo \& Leal, 2007); and Restrain eating, that is, the restrain of food consumption to manage and/or control body weight (Rebelo \& Leal, 2007; Viana \& Sinde, 2003). Individuals with obesity are more frequently involved in these eating behaviours, being associated with a greater severity of binge eating (Hilbert et al., 2007; Meule, Alison, \& Platte, 2014; Natacci \& Júnior, 2011; Schulz \& Laessle, 2010; Stice, 2002; van Strien, Frijters, Roosen, Knuiman-Hijl, \& Defores, 1985).

Binge eating is characterized by the lack of control of the quality and quantity of food intake throughout the time of 2 or less hours (American Psychiatric Association, 2013). This behaviour is preceded and followed by negative emotions, without inadequate compensatory behaviours to prevent weight gain (American Psychiatric Association, 2013; Leitão et al., 2013; Schag, Schönleber, Teufel, Zipfel, \& Giel, 2013). The binge eating behaviour differs from BED in relation to the frequency, i.e., to be considered BED, this behaviour has to occur at least once a week, during a period longer than 3 months; in addition, the individual with BED experiences 3 or more of the following symptoms: a) ingestion faster than usual; b) feeling uncomfortably full after exaggerated intake; c) ingestion of large quantities of food in the absence of hunger; d) ingestion of large quantities of food when alone (due to shame) and e) feelings of guilt, malaise 
and depressed mood after ingestion (American Psychiatric Association, 2013). Both pharmacological and psychological interventions (e.g., cognitive-behavioural therapy) have been shown to be effective in the treatment of binge eating (Cuadro \& Baile, 2015; Grilo, Masheb, \& Wilson, 2005).

Individuals who have obesity and binge eating differ from counterparts with obesity (and absence of binge eating): adults with obesity and binge eating have a more severe obesity degree and psychopathology (e.g., anxiety disorder) (Rosenbaum \& White, 2015; Striegel, Bedrosian, Wang, \& Schwartz, 2012; Tapadinhas \& Pais-Ribeiro, 2008); in addition, they are more likely to suffer from various conditions such as: physical diseases (e.g., arterial hypertension, type II diabetes mellitus) (Bulik, Sullivan, \& Kendler, 2002; Striegel et al., 2012; Mason \& Lewis, 2014; Mitchison, Mond, Slewa-Younan, \& Hay, 2013); practice less frequently physical activity (Bertoli et al., 2015; Vancampfort et al., 2014a; 2014b); have a greater dependence of nicotine and a lower probability of smoking cessation (Gruzca, Przybeck, \& Cloninger, 2007; White \& Grilo, 2007; White, Masheb, \& Grilo, 2010); and are more likely to binge eat when consuming alcoholic beverages (Stewart \& Brown, 2005).

In relation to the psychological and emotional dimensions, individuals with obesity and binge eating evaluate themselves by their weight and body shape (as a result of this, they express higher depressive symptoms, lower self-esteem, higher levels of perfectionism and dichotomy thoughts of either total control or lack of control of their eating behaviour) (Appolinário \& Claudino, 2000; Napolitano, Head, Babyak, \& Blumenthal, 2001). They exhibit more negative daily emotions due to the dissatisfaction with their lives and their relationships - feeling misunderstood with their BMI and eating behaviour, which increases their social isolation and, consequently, their uncontrolled food intake (Bernardi, Cichero, \& Vitolo, 2005; Zeeck, Stelzer, Linster, Joos, \& Hartmann, 2011). The aforementioned suggests that obesity per se does not induce severe psycho-emotional changes; these are more commonly observed in individuals who present concomitantly obesity and binge eating (Cuadro \& Baile, 2015; Horcajadas et al., 2006; Jambekar, Masheb, \& Grilo, 2003; Zeeck et al., 2011).

Regarding the socio-demographic characteristics, individuals with obesity who are older, have higher education, higher socioeconomic level, are in an affective-sexual relationship and are professionally active tend to practice less binge eating (Bertoli et al., 2015; Flegal, Carrol, Odgen, \& Curtin, 2010; Kessler et al., 2013; Peña \& Bacallao, 2000).

Thus, this research aims to explore factors associated with binge eating (i.e., eating behaviour, social support satisfaction, socio-demographic, health-related and lifestyle variables) in participants with obesity, living both on mainland Portugal and São Miguel Island, Azores. It also intends to investigate the differences between participants from mainland Portugal and those from São Miguel regarding the severity of binge eating and BMI.

\section{METHOD}

\section{Participants}

This study used a convenience sample of 187 participants of mainland Portugal $(n=117)$ and São Miguel Island, Azores $(n=70)$ with ages of 18 or above and a BMI equal or above $30 \mathrm{~kg} / \mathrm{m}^{2}$. These participants have a mean of age of 42 years old $(S D=14.36)$ and a mean BMI of $36 \mathrm{~kg} / \mathrm{m}^{2}(S D=4.97)$. Table 1 presents their characterization. 


\section{BINGE EATING IN OBESITY}

Table 1.

Participants' characterization

\begin{tabular}{|c|c|c|}
\hline Characteristics & $N$ & $\%$ \\
\hline \multicolumn{3}{|l|}{ Sex } \\
\hline Men & 58 & 31 \\
\hline Women & 129 & 69 \\
\hline \multicolumn{3}{|l|}{ Affective-sexual Relationship } \\
\hline Yes & 123 & 67.6 \\
\hline No & 59 & 32.4 \\
\hline \multicolumn{3}{|l|}{ Education Level } \\
\hline Primary School & 18 & 9.7 \\
\hline Basic Education & 40 & 21.6 \\
\hline High School & 48 & 25.9 \\
\hline University Education & 78 & 42.1 \\
\hline \multicolumn{3}{|l|}{ Professional Situation } \\
\hline Active & 122 & 65.6 \\
\hline Not active & 64 & 35.4 \\
\hline \multicolumn{3}{|l|}{ Annual Income } \\
\hline$\leq 10.000 €$ & 61 & 35.5 \\
\hline From 10.001 to $37.500 €$ & 88 & 51.2 \\
\hline From 37.501 to $70.000 €$ & 23 & 13.4 \\
\hline \multicolumn{3}{|l|}{ Physical Disease } \\
\hline Yes & 55 & 29.6 \\
\hline No & 131 & 70.4 \\
\hline \multicolumn{3}{|l|}{ Psychological Problem } \\
\hline Yes & 35 & 18.9 \\
\hline No & 150 & 81.1 \\
\hline \multicolumn{3}{|l|}{ Alcohol Consumption } \\
\hline Yes & 94 & 51.6 \\
\hline No & 88 & 48.4 \\
\hline \multicolumn{3}{|l|}{ Coffee Consumption } \\
\hline Yes & 139 & 74.7 \\
\hline No & 47 & 25.3 \\
\hline \multicolumn{3}{|l|}{ Tobacco Consumption } \\
\hline Yes & 56 & 30.1 \\
\hline No & 130 & 69.9 \\
\hline \multicolumn{3}{|l|}{ Physical Exercise } \\
\hline Yes & 98 & 53.3 \\
\hline No & 86 & 46.7 \\
\hline
\end{tabular}

\section{Materials}

\section{Binge Eating Scale}

The Binge Eating Scale (BES) developed by Gormally, Black, Daston and Rardin (1982), adapted to Portuguese by Tapadinhas and Pais-Ribeiro (2012), describes behaviours, feelings and cognitions associated to binge eating and consequently, classifies the severity of this behaviour. This measurement is composed of 16 items and the response scale ranges from absence to maximum severity of binge eating. The score assigned varies on a 3-point Likert-type scale, according to the guidelines proposed by the authors of the original scale. The final score refers to the degree of the severity of this compulsion, obtained by the sum of 
the points of each item. Thus, participants with scores less than or equal to 17 do not have binge eating, participants with scores between 18 and 26 have moderate binge eating and scores equal or greater than 27 have a severe degree of this clinical condition. This instrument has good psychometric qualities in both the original and adaptation studies (Gormally et al., 1982; Tapadinhas \& Pais-Ribeiro, 2012). The psychometric analysis performed in the present study has shown good properties, including a good fit of the confirmatory factor analysis $\left(X^{2} / d f=1.49, C F I=.97, T L I=.97, N F I=.92, R M S E A=.05\right.$ I.C. 90\%].03;.07 [ $\left.p<.05\right]$.

\section{Dutch Eating Behaviour Questionnaire}

The Dutch Eating Behaviour Questionnaire (DEBQ) by van Strien, Frijters, Bergers and Defares (1986) and adapted to Portuguese by Viana and Sinde (2003), evaluates the participants' eating behaviours. It is composed of 33 items, distributed by the 3 subscales, i.e., emotional eating, restrain eating and external eating. Responses are given on a 5-point Likert scale, which ranges from "never" to "very often"; the subscale with the higher score expresses the participants' most prominent eating pattern. This instrument showed good psychometric properties in the previous studies (van Strien et al., 1986; Viana \& Sinde, 2003). The confirmatory factor analysis, performed with the present sample, has demonstrated a good fit $\left(X^{2} / d f=1.83, C F I=.92, T L I=.92, N F I=.85\right.$, RMSEA $=.07$, I.C. $90 \%$ ].06;.07[ $\left.p<.001\right)$; additional analysis have also proven the scale both valid and reliable. The licence to use this instrument with the current sample has been validated with Boom Test Uitgevers, which hold the copyrights for this questionnaire (reference: $14 \mathrm{~b} 1422 \mathrm{jr})$.

\section{Social Support Satisfaction Scale}

The Social Support Satisfaction Scale (SSSS), built and validated by Pais-Ribeiro (1999) was used to evaluate participants' satisfaction with their social support. This measurement includes 15 statements, distributed through 4 subscales (i.e., satisfaction with the social support from friends, intimacy, family and social activities). The participant signals the degree of agreement with each item, using a 5-point Likert scale. The response scale ranges from "totally disagree" to "strongly agree". In addition to the 4 subtotals (resulting from each subscales) it is possible to calculate a global score - the highest score corresponds to the highest satisfaction with social support. The scale demonstrated good psychometrics properties (PaisRibeiro, 1999). Given the poor fit of SSSS on the confirmatory factor analysis, an exploratory factor analysis was done. Since the items from family support and intimacy subscales were disperse through the other 2 subscales (social activities and friends support), the first 2 subscales were excluded. The measure model, i.e., the subscales that kept their items (i.e., subscales of support from friends and social activities) had a good fit with the confirmatory factor analysis $\left(X^{2} / d f=1.09 ; C F I=.99 ; T L I=.99 ; N F I=.97 ; R M S E A=.02 ;\right.$ I.C. $90 \%$ ].001;.08[ $p<.05)$.

\section{Sociodemographic, Health and Lifestyle}

The socio-demographic, health and lifestyle questionnaires were used to characterize the participants in relation to sex, age, parity, affective-sexual relation, educational level, annual family income, physical and psychological self-reported health, BMI (according to the self-report of height and weight), tobacco, alcohol and coffee consumption, and physical exercise. 


\section{BINGE EATING IN OBESITY}

\section{Procedure}

A non-probabilistic convenience sample was used; the sample was recruited in mainland Portugal and São Miguel, Azores, both in clinical (e.g., hospital, clinical nutrition) and community settings (including obesity-related online forums). The data collection was done online and in pencil-paper format. The study was approved by the Ethics Committee of Hospital de Santa Maria (in Lisbon). After obtaining the authorizations of these institutions, the study was presented to the health professionals (namely, psychologists and medical doctors) who worked directly with patients with obesity. These professionals established contact with their users, informing about the present research. If these users were interested in integrating it, these professionals gave the researchers this information. Afterwards, a psychologist from the research team contacted the aforementioned individuals by telephone, email or in person to apply the screening questionnaire, to verify if they met the inclusion criteria. If these criteria were confirmed, the participants received an informed consent (which explained the aims of the study, highlighting that the participation was voluntary and they could interrupt their collaboration at any time without consequences). After the informed consent was agreed with and signed, the participants answered the questionnaire.

\section{Statistical Analysis}

Missing values were imputed for variables with a missing frequency lower than 10 per cent of the sample. A student's t-test was applied (regarding binge eating, eating behaviour, social support satisfaction and BMI) to analyse the differences between participants who completed the questionnaire either online or in paperpencil format. Then structural equations modelling was used. A two-step modelling approach was used to assess the structural model. First, the factor's measurement model was evaluated to demonstrate a good fit. Afterwards, the structural model, encompassing the dependent variable (binge eating) and the independent variables (socio-demographic, health-related, lifestyle, eating behaviour and satisfaction with social support) was adjusted and the significances of the trajectories were evaluated (Maroco, 2014). Finally, a student's ttest was used to investigate the existence of differences regarding binge eating and BMI, between the participants from mainland Portugal and those from São Miguel Island. For that process the Statistical Package for Social Sciences - SPSS, version 23.0 was utilized, as well as the Analysis of Moment Structure AMOS 22.0.

\section{RESULTS}

The measurement model presented a good fit $\left(X^{2} / d f=1.52 ; C F I=.91 ; T L I=.9 ; R M S E A=.05\right.$ I.C.90\% ].05;.06[ $p<.05)$. Afterwards, the quality of the structural model was explored and an acceptable fit was shown $\left(X^{2} / d f=1.72 ; C F I=.81 ; T L I=.8 ; R M S E A=.06\right.$ I.C. $\left.90 \%\right] .06 ; .07[p<.001)$.

Since the model had a good fit, the predictors of binge eating were subsequently analysed. Several independent variables were associated with binge eating, such as emotional eating $(\beta=.26 ; p<.001)$, external eating $(\beta=.2 ; p<.001)$, social support satisfaction from friends $(\beta=-.14 ; p=.004)$, and educational level $(\beta=-$ $.11 ; p<.001$ ) (as shown in Table 2); the significant predictors account for $45.4 \%$ of the variability of the binge eating presented by this sample. 


\section{Table 2.}

Trajectories Between the Binge Eating, Eating Behaviour (Emotional Eating, External Eating and Restrain Eating), Social Support Satisfaction (Friends and Social Activities), Sociodemographic, Health and Lifestyle Variables.

\begin{tabular}{lccc}
\hline Trajectories & $\boldsymbol{\beta}$ & $\boldsymbol{S E}$ & $\boldsymbol{P}$ \\
\hline Binge Eating $\square \square$ S.S.S. Friends & -.14 & .04 &. $\mathbf{0 0 4}$ \\
Binge Eating $\square \square$ S.S.S. Social Activities & .02 & .04 & .58 \\
Binge Eating $\square \square$ Emotional Eating & .26 & .04 & $* * *$ \\
Binge Eating $\square \square$ External Eating & .2 & .04 & $* * *$ \\
Binge Eating $\square \square$ Restrain Eating & .08 & .06 & .14 \\
Binge Eating <- BMI & .003 & .007 & .68 \\
Binge Eating $\square \square$ Age & .002 & .002 & .35 \\
Binge Eating <- Sex & .08 & .07 & .24 \\
Binge Eating $\square \square$ Affective-Sexual Relationship & .13 & .07 & .07 \\
Binge Eating $\square \square$ Number of Children & .003 & .02 & .91 \\
Binge Eating $\square \square$ Educational Level & -.11 & .03 & $* * *$ \\
Binge Eating $\square \square$ Professional Situation & -.05 & .07 & .49 \\
Binge Eating $<-$ Annual Income & .03 & .03 & .26 \\
Binge Eating $\square \square$ Physical Disease & .08 & .07 & .26 \\
Binge Eating $\square \square$ Psychological Problem & .09 & .08 & .28 \\
Binge Eating $\square \square$ Physical Exercise & .05 & .06 & .43 \\
Binge Eating $\square \square$ Tobacco Consumption & .09 & .07 & .19 \\
Binge Eating $\square \square$ Alcohol Consumption & -.11 & .06 & .10 \\
Binge Eating $\square \square$ Coffee Consumption & .11 & .07 & .13 \\
\hline
\end{tabular}

$* * * p<.001$

There were differences between participants who completed the questionnaire in online format and in paper-pencil format regarding to external eating $(t(185)=3.13 ; p=.002)$ and BMI $(t(119,467)=-5.13 ; p=.001)$. Finally, there were no differences between the participants of mainland Portugal and those from São Miguel regarding to binge eating $(t(115,897)=-1.38 ; p=.17)$. Although, there were differences in the BMI between participants of São Miguel $(M=34.87 ; D P=3.18)$ and mainland Portugal $(M=37.17 ; D P=5.63)$, the highest mean BMI was observed in the mainland and not in São Miguel $(t(184,538)=3.57 ; p=.001)$.

\section{DISCUSSION}

In this study, emotional eating predicts binge eating, as according to literature. Individuals with obesity who face a negative emotion tend to practice an excessive and uncontrolled intake of food, in opposition to people with a healthy weight that, normally, evidenced more adaptive strategies (Match, Haupt, \& Ellring, 2005). In addition, it is known that negative emotions can result in food intake, which stimulates the production and circulation of neurotransmitters responsible for momentary feelings of well-being; the latter might explain binge eating recurrence and, consequently, their higher severity (Match, Haupt, \& Ellring, 2005; Match \& Simons, 2000; Masheb \& Grilo, 2006; Pinto-Bastos, Ramalho, Conceição, \& Mitchell, 2016).

The association between external eating and binge eating was verified, as mentioned by previous 


\section{BINGE EATING IN OBESITY}

researches (Schulz \& Laessle, 2010; Poínhos, Oliveira, \& Correia, 2013; Racine, Culbert, Larson, \& Klump, 2009): an easy accessibility to toxic food environments leads to a greater binge eating severity, associated to higher frequency of external eating. Therefore, it is important to implement interventions that promote adaptive coping strategies so that these individuals do not resort to either emotional or external eating.

In opposition, binge eating is not predicted by restrain eating. Paradoxically, Andrés and Saldaña (2014) demonstrated that individuals with obesity and binge eating report higher frequency in diet practice, compared to counterparts without this type of ingestion. Nonetheless, according to Azevedo, Santos and Fonseca (2004), while some of these people resort to food restriction, others abandon this restriction due to successive failures experienced in this field.

Additionally, there was no association between satisfaction with social activities and binge eating. Yet, binge eating is negatively predicted by satisfaction with friends. Individuals less satisfied with their social support from friends experienced higher severity of binge eating; similarly, literature indicates that the poor perception of social support is inversely associated to healthy behaviours; the contact with friends is associated to less risk of development eating disorders and, consequently, to less severe binge eating (Almeida, Savoy, \& Baxer, 2011; Hefner \& Eisenberg, 2009; Mason \& Lewis, 2016). The practice of binge eating is associated with dysfunctional interpersonal relationships - Individuals with binge eating present feelings of isolation, justified by their dissatisfaction with their relationships (Zeeck et al., 2011). Thus, it is important to promote interpersonal relationships, which promote meaningful friend relationships and favour the experience of emotions and feelings of belonging; these might counteract feelings of exclusion and miscomprehension that people with obesity may experience. Therefore, activities that stimulate healthpromoting practices (e.g., walking trails) with friends may have a positive impact on binge eating.

Rosenberger and Dorflinger (2013) and Tapadinhas and Pais-Ribeiro (2012) concluded that BMI and binge eating had no association. However, according to the Hudson, Hiripi, Pope, Kessler, and Pope (2007) only BMI above $40 \mathrm{~kg} / \mathrm{m}^{2}$ is associated with a higher severity of binge eating. The fact that only $23 \%$ of the participants of the present study had a BMI equal or above to $40 \mathrm{~kg} / \mathrm{m}^{2}$ might explain the lack of association between both BMI and binge eating. In addition, participants may be ashamed to assume this behaviour, due to the awareness that it is a dysfunctional behaviour (Quadros, Bruscatos, \& Filho, 2006) and thus, undereport its severity.

The comparison of the 2 subsamples from 2 different Portuguese regions - mainland Portugal and São Miguel, Azores - showed that there were differences in BMI distribution: unlike the literature (Instituto Nacional de Estatística, 2015), the prevalence of obesity was higher in the subsample of mainland Portugal. Reflecting about this result, sampling bias cannot be excluded: the mainland sample was mainly collected in clinical settings whereas the Azores sample was mainly collected in community settings. However, there were no differences between the participants of São Miguel and those from mainland Portugal in relation to binge eating.

There were a marginally significant association between binge eating and the existence of an affectivesexual relationship: people with partners tended to have a higher binge eating severity. However, individuals reporting more frequent binge eating describe a negative interaction with their partners (Freitas, Appolinario, Souza, \& Sichieri, 2008; Whisman, Dementyeva, Baucom, \& Bulik, 2012). Schulz and Laessler (2009) supports: this type of ingestion is often precipitated by conflicting relationships. In this way, it could be beneficial to contemplate couples therapy, in the context of clinical treatment of binge eating, when low satisfaction with the partner relationship is present.

As far as educational level, it is associated with binge eating in the present study, i.e., individuals with lower educational level tended to experience higher severity of binge eating. This result is in agreement with 
what is expressed in the literature (Kessler et al., 2013). The above may be related to higher knowledge, personal and social resources of these individuals in relation to the selection of foods to be eaten and management of eating behaviours and, consequently, binge eating.

There was no association between binge eating and the participants' professional status. However, according to a previous study (Peña \& Bacallao, 2000), individuals in an inactive professional situation evidenced more binge eating behaviours. It is added that active individuals, who report binge eating, present greater limitations in the fulfilment of their occupational function (Mitchison et al., 2013).

Also, there was no association between binge eating and psychological problems, but several studies show this relationship (Matos et al., 2002). Similar researches conclude that individuals with obesity and binge eating develop various psychological difficulties or stressful events: feelings of dissatisfaction with their body, exposure to negative comments regarding their body, weight, eating behaviours and feelings of loss of control associated with binge eating episodes (Cuadro \& Baile, 2015; de Zwaan, 2001). Similarly, there was no association between physical health and binge eating although Bulik, Sullivan and Kendler (2002) concluded that binge eating is associated with medical morbidities. However, the way in which psychological problems and physical illnesses were measured (i.e., dichotomous responses to the questions "Have you had any psychological problems recently?"; "Have you recently had any physical disease(s)?") may lead to overly general answers. The objective being to ascertain the relationship between a specific psychological/physical condition and the severity of a binge eating behaviour, i.e., the nature of these problems may result in heterogeneity of problems. Thus, it would be pertinent to develop a study to evaluate if high severity binge eating could be linked to the presence of specific clinical conditions such as (for example) cardiovascular disease.

This study presents several limitations, namely, the sampling technique used (convenience sample), which does not allow the results generalization; a sub-representation of men $(69 \%$ of the sample are women); the impossibility of establishing a causal relation between the variables under study, evidencing the pertinence of a longitudinal study; the obtained differences in the distribution of external eating and BMI, when comparing the data collected through an online format and paper-pencil format.

In conclusion, less frequency of external and emotional eating, higher satisfaction with social support from friends and higher educational levels predict lower severity of binge eating.

\title{
ACKNOWLEDGMENTS
}

\begin{abstract}
Grant SFRH/BPD/77799/2011 from the Portuguese Fundação para a Ciência e Tecnologia, FCT TSËP]
\end{abstract}

\section{REFERENCES}

Almeida, L., Savoy, S., \& Boxer, P. (2011). The role of weight stigmatization in cumulative risk for binge eating. Journal of Clinical Psychology, 67, 278-292. doi: 10.1002/jclp.20749.

American Psychiatric Association (2013). Diagnostic and statistical manual of mental disorders. (5th

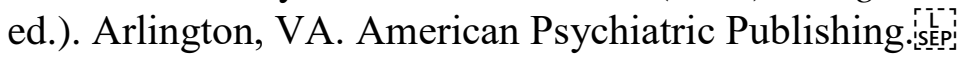

Andrés, A., \& Saldaña, C. (2014). Body dissatisfaction and dietary restraint influence binge eating behavior. Nutrition Research, 34, 944-950. doi: 10.1016/j.nutres.2014.09.003. 


\section{BINGE EATING IN OBESITY}

Appolinário, J. C., \& Claudino, A. M. (2000). Transtornos Alimentares. Revista Brasileira de Psiquiatria, 22(2), 28-31. doi: 10.1590/S1516-44462000000600008.

Azevedo, A. P., Santos, C. C., \& Fonseca, D. C. (2004). Transtorno da compulsão alimentar periódica. Revista de Psiquiatria Clínica, 31(4), 170-172. doi: 10.1590/S0101-60832004000400008.

Bernardi, F., Cichelero, C., \& Vitolo, M. R. (2005). Comportamento de restrição alimentar e obesidade. Revista de Nutrição, 18(1), 85-93. doi: 10.1590/S1415-52732005000100008.

Bertoli, S., Leone, A., Ponissi, V., Bedogni, G., Beggio, V., Strepparava, M. G., \& Battezzati, A. (2015). Prevalence of and risk factors for binge eating behaviour in 6930 adults starting a weight loss or maintenance programme. Public Health Nutrition, 1-7. doi: 10.1017/S1368980015001068.

Bulik, C. M., Sullivan, P. F., \& Kendler, K. S. (2002). Medical and Psychiatric Morbidity in Obese Women with and without Binge Eating. International Journal of Eating Disorders, 32, 72-78. doi: 10.1002/eat.10072.

Cuadro, E., \& Baile, J. I. (2015). Binge eating disorder: analysis and treatment. Revista Mexicana de Transtornos Alimentarios, 6(2), 97-107. doi: 10.1016/j.rmta.2015.10.001.

de Zwaan, M. (2001). Binge eating disorder and obesity. International Journal of Obesity, 25(1), 51-55. doi: 10.1038/sj.ijo.0801699.

Flegal, K. M., Carrol, M. D., Ogden, C. L., \& Curtin, L. R. (2010). Prevalence and Trends in Obesity among US Adults, 1999-2008, The Journal of the American Medical Association, 303(3), 235-241. doi: 10.1001/jama.2009.2014.

Freitas, S. R., Appolinario, J. C., Souza, A. M., \& Sichieri, R. (2008). Prevalence of BE and associated factors in a Brazilian probability sample of midlife women. International Journal of Eating Disorders, 41, 471-478. doi: 10.1002/eat.20530.

Gormally, J., Black, S., Daston, S., \& Rardin, D. (1982). The Assessment of Binge Eating Severity Among Obese Persons. Addictive Behaviors, 7, 47-55. doi: 10.1016/0306-4603(82)90024-7.

Grilo, C. M., Masheb, R. M., \& Wilson, G. T. (2005). Efficacy of cognitive behavioral therapy and fluoxetine for the treatment of binge eating disorder: A randomized double-blind placebo-controlled comparison. Biological Psychiatry, 57(3), 301-309. doi: 10.1016/j.biopsych.2004.11.002.

Grucza, R. A., Przybeck, T. R., \& Cloninger, R. C. (2007). Prevalence and correlates of binge eating disorder in a community sample. Comprehensive Psychiatry, 48, 124-131. doi: 10.1016/j.comppsych.2006.08.002.

Guenter, R. (2000). A obesidade feminina. Análise Psicológica, 18(1), 59-70. doi: 10.14417/ap.422.

Hefner, J., \& Eisenberg, D. (2009). Social support and mental health among college students. American Journal of Orthopsychiatry, 79, 491-499. doi: 10.1037/a0016918.

Hilbert, A., Saelens, B. E., Stein, R. I., Mockus, D. S., Welch, R. R., \& Matt, G. E. (2007). Pretreatment and process predictors of outcome in interpersonal and cognitive behavioral psychotherapy for binge eating disorder. Journal of Consulting and Clinical Psychology, 75, 645-651. doi: 10.1037/0022-006X.75.4.645.

Horcajadas, F., Romero, S., Martínez, J., Ruiz, F., Rojo, F., \& Martin, F. (2006). Clinical differences between morbid obese patients with and without binge eating. Actas Espanholas de Psiquiatria, 34(6), 36270 .

Hudson, J. I., Hiripi, E., Pope, H. G., Kessler, R., \& Pope, Jr. (2007). The prevalence and correlates of eating disorders in the national comorbidity survey replication. Biological Psychiatry, 6, 348-358. doi: 10.1016/j.biopsych.2006.03.040.

Instituto Nacional de Estatística. (2015). Inquérito Nacional de Saúde. (2016, December 15). Retrieved 
from

https://www.ine.pt/xportal/xmain?xpid=INE\&xpgid=ine_destaques\&DESTAQUESest_boui=224733757\&D ESTAQUESmodo=2\&xlang=pt.

Jambekar, S. A., Masheb, R. M., \& Grilo, C. M. (2003). Gender Differences en Shame in Patients with Binge-Eating Disorder. Obesity Research, 11, 571-577. doi: 10.1038/oby.2003.80.

Kessler, R. C., Berglund, P. A., Chiu, W. T., Deitz, A. C., Hudson, J. I., Shahly, V.,... Xavier, M. (2013). The prevalence and correlates of binge eating disorder in the World Health Organization World Mental Health Surveys. Biological Psychiatry, 73, 904-914. doi: 10.1016/j.biopsych.2012.11.020.

Leitão, M., Pimenta, F., de Herédia, T., \& Leal, I. (2013). Comportamento alimentar, compulsão alimentar, história de peso e estilo de vida: diferenças entre pessoas com obesidade e com uma perda de peso bem-sucedida. Alimentos e Nutrição=Brazilian Journal of Food and Nutrition, 24(4), 393-401.

Macht, M., Haupt, D., \& Ellring, H. (2005). The perceived function of eating is changed during examination stress: a field study. Eating Behaviors, 6, 109-112. doi: 10.1016/j.eatbeh.2004.09.001.

Macht, M., \& Simons, G. (2000). Emotions and eating in everyday life. Appetite, 35, 65-71. doi: 10.1006/appe.2000.0325.

Magalhães, P., \& Motta, D. G. (2012). Uma abordagem psicossocial do estado nutricional e do comportamento alimentar de estudantes de nutrição. Alimentos e Nutrição=Brazilian Journal of Food and Nutrition, 37(2), 118-132. doi: 10.4322/nutrire.2012.010.

Maroco, J. (2014). Análise de equações estruturais: fundamentos teóricos, software e aplicações. $2 \mathrm{nd}$ ed. Pêro Pinheiro: Report Number.

Masheb, R. M., \& Grilo, C. M. (2006). Emotional overeating and its associations with eating disorder psychopathology among overweight patients with Binge eating disorder. International Journal of Eating Disorders, 39(2), 141-146. doi: 10.1002/eat.20221.

Mason, T. B., \& Lewis, R. J. (2014). Profiles of binge eating: the interaction of depressive symptoms, eating styles, and body mass index. Eating Disorders: The Journal of Treatment and Prevention, 22, 450460. doi: 10.1080/10640266.2014.931766.

Mason, T. B. \& Lewis, R. J. (2016). Examining social support, rumination, and optimism in relation to binge eating among Caucasian and African-American college women. Eating and Weight Disorders. doi: 10.1007/s40519-016-0300-x.

Matos, M. I., Aranha, L. S., Faria, A. N., Ferreira, S. R., Bacaltchuck, J., \& Zanella, M. T. (2002). Compulsão alimentar periódica, ansiedade, depressão e imagem corporal em pacientes com obesidade grau III. Revista Brasileira de Psiquiatria, 24(4), 165-169. doi: 10.1590/S1516-44462002000400004.

Meule, A., Allison, K. C., \& Platte, P. (2014). Emotional Eating Moderates the Relationship of Night Eating with Binge Eating and Body Mass. European Eating Disorders Review, 22, 147-151. doi: 10.1002/erv.2272.

Mitchison, D., Mond, J., Slewa-Younan, S., \& Hay, P. (2013). Sex differences in health related quality of life impairment associated with eating disorder features: a general population study. International Journal of Eating Disorders, 46, 375-380. doi: 10.1002/eat.22097.

Napolitano, M. A., Head, S., Babyak, M. A., \& Blumenthal, J. A. (2001). Binge Eating Disorder and Night Eating Syndrome: Psychological and Behavioral Characteristics. International Journal of Eating Disorders, 30, 193-203. doi: 10.1002/eat.1072.

Natacci, L. C., \& Júnior, M. F. (2011). The three factor eating questionnaire - R21: tradução para o português e aplicação em mulheres brasileiras. Revista de Nutrição, 24(3), 383-394. 


\section{BINGE EATING IN OBESITY}

52732011000300002 .

Nguyen-Rodriguez, S. T., Unger, J. B., \& Spruijt-Metz, D. (2009). Psychological Determinants of Emotional Eating in Adolescence. Journal Eating Disorders, 17(3), 211-224. doi: 10.1080/10640260902848543.

Pais-Ribeiro, J. L. (1999). Escala de Satisfação com o Suporte Social (ESSS). Análise Psicológica, 3(16), 547-558.

Peña, M., \& Bacallao, J. (2000). La obesidad en la pobreza: un problema emergente en las Américas. In M. Peña, \& J. Bacallao (Ed). La Obesidad en la Pobreza- un Nuevo Reto para La Salud Publica (pp.311).Washington, DC: Organización Panamericana de la Salud.

Pfattheicher, S., \& Sassenrath, C. (2014). A regulatory focus perspective on eating behavior: how prevention and promotion focus relates to emotional, external, and restrained eating, Frontiers in Psychology, 5, 1-8. doi: 10.3389/fpsyg.2014.01314.

Pinto-Bastos, A., Ramalho, S., Conceição, E., \& Mitchell, J. (2016). Disorderer Eating and Obesity. In S. Ahmad, \& S. Iman (Ed.). Obesity: A Practical Guide (pp. 309-316). London, UK: Springer. doi: 10.1007/978-3-319-19821-7.

Poínhos, R., Oliveira, B., \& Correia, F. (2013). Eating behaviour patterns and BMI in Portuguese higher education. Appetite, 71, 314-320. doi: 10.1016/j.appet.2013.08.024.

Quadros, M. R., Bruscato, G. T., \& Filho, A. J. (2006). Compulsão Alimentar em Pacientes no PréOperatório de Cirurgia Bariátrica. Psicologia Argumento, 24(45), 59-65.

Racine, S. E., Culbert, K. M., Larson, C. L., \& Klump, K. L. (2009). The possible influence of impulsivity and dietary restraint on associations between serotonin genes and binge eating. Journal of Psychiatric Research, 43, 1278-1286. doi: 10.1016/j.jpsychires.2009.05.002.

Rebelo, A., \& Leal, I. (2007). Factores de personalidade e comportamento alimentar em mulheres portuguesas com obesidade mórbida: estudo exploratório. Análise Psicológica, 25(3), 467-477. doi: 10.14417/ap.458.

Rosenbaum, D. L., \& White, K. S. (2015). The relation of anxiety, depression, and stress to binge eating behavior. Journal of Health Psychology, 20(6), 887-898. doi: 10.1177/1359105315580212.

Rosenberger, P., \& Dorflinger, L. (2013). Psychosocial factors associated with binge eating among overweight and obese male veterans. Eating Behaviors, 14(3), 401-404. doi: 10.1016/j.eatbeh.2013.06.006.

Schag, K., Schönleber, J., Teufel, M., Zipfel, S., \& Giel, K. E. (2013). Food-related impulsivity in obesity and binge eating disorder - a systematic review. Obesity Reviews, 14, 477-495. doi: 10.1111/obr.12017.

Schulz, S., \& Laessle, R. G. (2009). Stress-induced laboratory eating behavior in obese women with binge eating disorder. Appetite, 58(2), 457-461. doi: 10.1002/eat.20648.

Schulz, S., \& Laessle, R. G. (2010). Associations of negative affect and eating behavior in obese women with and without binge eating disorder. Eating and Weight Disorders, 15(4), 287-293. doi: 10.1007/BF03325311.

Stewart, S., \& Brown, C. (2005). Challenges in understanding the co-prevalence of disordered eating and substance use problems and in responding with integrated services. In: L. Greaves, N. Poole, \& J. (Eds.). Women and Substance Use: Current Canadian Perspectives (pp.355-362). Toronto: Centre for Addiction and Mental Health.

Stice, E. (2002). Sociocultural influences on body image and eating disturbance. In C. Fairburn, (Ed.). Eating disorders and obesity: A comprehensive Handbook (2nd ed.) (pp. 103-107). New York: The Guilford Press. 
Striegel, R. H., Bedrosian, R., Wang, C., \& Schwartz, S. (2012). Why men should be included in research on binge eating: Results from a comparison of psychosocial impairment in men and women. International Journal of Eating Disorders, 45, 233-240. doi: 10.1002/eat.20962.

Tapadinhas, A. R., \& Pais-Ribeiro, J. (2008). Ingestão Compulsiva e Gestão das Emoções na Obesidade. In I. Leal, J.Pais-Ribeiro, I. Silva \& S.Marques (Eds.). Actas 7 o Congresso Nacional de Psicologia da Saúde (pp.85-88). Lisboa: ISPA.

Tapadinhas, A. R., \& Pais-Ribeiro, J. (2012). Validação da Escala de Ingestão Compulsiva (BES) - Um estudo com uma amostra de obesos portugueses. In J.Pais-Ribeiro, I. Leal, A. Pereira, A. Torres, I. Direito, \& P. Vagos (Eds.). Actas 9o Congresso Nacional de Psicologia da Saúde (pp.31-36). Lisboa: Placebo, Editora LDA.

Vancampfort, D., De Herdt, A., Vanderlinden, J., Lannoo, M., Soundy, A., Pieters, G.,... Probst, M. (2014a). Health related quality of life, physical fitness and physical activity participation in treatmentseeking obese persons with and without binge eating disorder. Psychiatry Research, 216, 97-102. doi: 10.1016/j.psychres.2014.01.015.

Vancampfort, D., Probst, M., Adriaens, A., Pieters, G., De Hert, M., Soundy. A,.. Vanderlinden, J. (2014b). Clinical correlates of global functioning in obese treatment seeking persons with binge eating disorder. Psychiatria Danubina, 26, 256-260.

Van Strien, T., Frijters, J. E., Roosen, R. G., Knuiman-Hijl, W. J., \& Defores, P. B. (1985). Eating behavior, personality traits and body mass in women. Addictive Behaviors, 10, 333-343. doi: 10.1016/03064603(85)90029-2.

Van Strien, T., Frijters, J. E., Bergers, G. P., \& Defares, P. B. (1986). The Dutch Eating Behavior Questionnaire (DEBQ) for assessment of restrained, emotional, and external eating behavior. International Journal of Eating Disorders, 5, 295-315. doi: 10.1002/1098-108X(198602)5:2<295::AIDEAT2260050209>3.0.CO;2-T.

Venzon, C. N., \& Alchieri, J. C. (2014). Indicadores de Compulsão Alimentar Periódica em Pósoperatório de Cirurgia Bariátrica. Psico, 45(2), 239-249. doi: 10.15448/1980-8623.2014.2.14806.

Viana, V., \& Sinde, S. (2003). Estilo Alimentar: adaptação e validação do Questionário Holandês do Comportamento Alimentar. Psicologia: Teoria, Investigação e Prática, 1, 59-71.

Whisman, M. A., Dementyeva, A., Baucom, D. H., \& Bulik, C. M. (2012). Marital functioning and binge eating disorder in married women. International Journal of Eating Disorders, 5, 385-389. doi: 10.1002/eat.20935.

White, M. A., \& Grilo, C. M. (2007). Symptom Severity in Obese Women with Binge Eating Disorder as a Function of Smoking History. International Journal of Eating Disorders, 40(1), 77-81. doi: 10.1002/eat.20334.

White, M. A., Masheb, R. M., \& Grilo, C. M. (2010). Self-reported weight gain following smoking cessation: a function of binge eating behavior. International Journal of Eating Disorders, 43, 572-575. doi: 10.1016/j.addbeh.2015.09.018.

World Health Organization. (2000). Technical report series 894: Obesity: Preventing and managing the global epidemic. Geneva: World Health Organization.

World Health Organization. (2015). Obesity and Overweight. (Fact sheet no311). (2016, December 15). Retrieved from http://www.who.int/mediacentre/factsheets/fs311/en/.

Zeeck, A., Stelzer, N., Linster, H., Joos, A., \& Hartmann, A. (2011). Emotion and eating in binge eating disorder and obesity. European Eating Disorders Review, 19, 426-437. doi: 10.1002/erv.1066. 